\title{
Profile of Chromosomal Abnormalities in the Al Jahra Region of Kuwait
}

\author{
R.L. Al-Naggar ${ }^{a}$ S.A. Mady ${ }^{b}$ S.M. Tayela T.I. Farag ${ }^{a}$ \\ S.A. Al-Awadi ${ }^{a}$ M.M. Al-Ghanimb ${ }^{b}$ S.J. Abulhasan ${ }^{a}$ M.A. Sabry ${ }^{a}$ \\ L. Bastakia \\ a Medical Genetics Centre, Maternity Hospital, and \\ bPaediatric Department, Al-Jahra Hospital, Kuwait
}

\section{Key Words}

Chromosomal abnormalities, numerical and structural - Down's syndrome - Trisomy 18 .

Deletion · Duplication · Inversion

\begin{abstract}
Objective: One hundred and seventy-seven newborn babies with chromosomal abnormalities were studied at the Al-Jahra satellite clinic of the Kuwait Medical Genetics Centre (KMGC), Kuwait, over a 7-year period from January 1983 to December 1989 to make a reanalysis and recomputation of the statistical results of the previous short-term studies. Methods: The data were collected from the registry of chromosomal abnormalities and from the clinical records of the patients in KMGC retrospectively. Controls were selected from the newborn babies delivered in the same period of study. The logistic regression analysis was computed using dependent/ independent variables. Results: Ninety-five percent of the cases had numerical chromo-
\end{abstract}

\begin{tabular}{ll}
\hline KARGER & (1) 1999 S. Karger AG, Basel \\
1011-7571/99/0083-0167\$17.50/0 \\
Fax +4161306 1234 & \\
$\begin{array}{l}\text { E-Mail karger@karger.ch } \\
\text { www.karger.com }\end{array}$ & $\begin{array}{l}\text { Accessible online at: } \\
\text { http://BioMedNet.com/karger }\end{array}$
\end{tabular}

somal abnormalities, and $5 \%$ had structural chromosomal abnormalities. One hundred and forty-five cases had classic trisomy 21, with an incidence of 2.9/1,000 live births (LB), 16 cases had trisomy $18(0.3 / 1,000 \mathrm{LB}), 5$ cases had trisomy $13(0.1 / 1,000$ LB), 1 case had triploidy 69, XXY (0.02/1,000 LB) and 1 had Turner's syndrome $(0.05 / 1,000$ female LB). Nine cases with structural chromosomal abnormalities were enumerated, dir dup(1) (p21-p32), del(1)(q32-q42), del(13)(q22-q34) and inversion $Y$ chromosome, the incidence was $0.02 / 1,000$ LB for each. Two cases of translocation trisomy $21(0.04 / 1,000$ LB) and 3 cases of cri-du-chat $(0.06 / 1,000$ LB) were enumerated too. Bedouins had a double-fold increased risk of trisomy 21 (odds ratio = $1.819, p=0.032$ ), and advanced maternal age was also a risk factor while paternal age showed inconsistent pattern of risk. Conclusion: This study confirmed the high incidence of the common trisomies and the role of advanced maternal age and the Bedouin ethnicity as a risk factor.
Kuwait Medical Genetics Centre PO Box 31121

80901 Sulaibikhat (Kuwait) 


\section{Introduction}

Chromosomal abnormalities involve numerical and structural aberrations. The loss or duplication of an individual and/or the entire set of chromsomes is referred to as aneuploidy. Structural rearrangement results from chromosomal breakage followed by abnormal reunion. The common structural aberrations include translocation (balanced, unbalanced, reciprocal and robertsonian), deletion, inversion, duplication, ring chromosome and isochromosome [1]. Chromosomal analysis was ascertained at the Al-Jahra Hospital, Kuwait, which serves an Arab population of about $300,000,80 \%$ of whom belong to the Bedouin ancestry. Most of the studies on chromosomal abnormalities carried out in the same area were not comprehensive [2-8]. Classic trisomy 21 and trisomy 18 were the most common trisomies. There was also clustering of cri-du-chat syndrome [46, XY, del(5)(p14)]. The aim of this relatively longterm study was to provide a more comprehensive profile of the chromosomal abnormalities in the Al-Jahra region of Kuwait, and to compare the findings with the world-wide surveys.

\section{Patients and Methods}

The study population included 177 cases of chromosomal abnormalities from among 49,174 live births registered at the Al-Jahra Hospital from January 1983 to December 1989. Data in this retrospective study were collected from the registry for chromosomal abnormalities of the Kuwait Medical Genetics Centre and from the patients' clinical records. The data included history of the patient, a three-generation deep family pedigree, thorough clinical evaluation, cytogenetic results and statistical analysis of the risk factors such as ethnicity, maternal and paternal age effect. A group-matched case control study was undertaken in which 145 healthy live births were used as controls for the 145 trisomy- 21 cases. Controls were selected from the newborns delivered during the same month of the
Table 1. Frequency/incidence of numerical and structural chromosomal abnormalities

\begin{tabular}{lrrl}
\hline $\begin{array}{l}\text { Chromosomal } \\
\text { abnormality }\end{array}$ & $\begin{array}{l}\text { Cases } \\
\mathrm{n}\end{array}$ & $\begin{array}{l}\text { Frequency } \\
\%\end{array}$ & $\begin{array}{l}\text { Incidence per } \\
1,000 \text { live births }\end{array}$ \\
\hline $\begin{array}{l}\text { Numerical } \\
\text { Structural }\end{array}$ & $\begin{array}{r}168 \\
9\end{array}$ & $\begin{array}{r}94.9 \\
5.1\end{array}$ & $\begin{array}{l}3.4 \\
0.2\end{array}$ \\
\hline Total & 177 & 100.0 & 3.6 \\
\hline
\end{tabular}

Table 2. Classification/percentages of Down's syndrome cases

\begin{tabular}{lrc}
\hline Trisomy 21 & \multicolumn{2}{l}{ Cases } \\
\cline { 2 - 3 } & $\mathrm{n}$ & $\%$ \\
\hline Regular type & 144 & 97.9 \\
$\begin{array}{l}\text { Mosaic } \\
\text { Translocation }\end{array}$ & 1 & 0.7 \\
\hline Total & 147 & 100 \\
\hline a This low frequency of translocation 21 cases could \\
$\begin{array}{l}\text { by explained by the possibility of missing cases before } \\
\text { the clinical and the cytogenetic assessments. }\end{array}$
\end{tabular}

birth of the trisomy 21 cases. Logistic regression analysis was carried out using the variable status ( 0 for controls, and 1 for trisomy 21 cases) as the dependent variable, and ethnicity, maternal and paternal age as independent variables.

\section{Results}

Cases with chromosomal abnormalities represented $16.7 \%$ of the total number of cases with congenital malformations (948 cases) ascertained in the present study. The frequency and the incidence of numerical versus structural chromosomal aberrations are shown in table 1. Down's syndrome cases represented $83.1 \%$ of the total chromosomal abnormalities. Classical Down's syndrome presented

\section{8}

Med Principles Pract 1999;8:167-172
Al-Naggar/Mady/Tayel/Farag/ Al-Awadi/Al-Ghanim/Abulhasan/ Sabry/Bastaki 
Table 3. Crude incidence and sex ratio among numerical chromosomal aberration cases

\begin{tabular}{lrll}
\hline $\begin{array}{l}\text { Numerical } \\
\text { chromosomal aberration }\end{array}$ & $\begin{array}{l}\text { Cases } \\
\mathrm{n}\end{array}$ & $\begin{array}{l}\text { Sex ratio } \\
\mathrm{M} / \mathrm{F}\end{array}$ & $\begin{array}{l}\text { Incidence per } \\
1,000 \text { liver births }\end{array}$ \\
\hline Regular Down's syndrome & 145 & $2: 1$ & 2.9 \\
Trisomy 18 & 16 & $1: 3$ & 0.3 \\
Trisomy 13 & 5 & $1: 4$ & 0.1 \\
\hline
\end{tabular}

Table 4. The risk of trisomy 21 by maternal age at delivery

\begin{tabular}{llll}
\hline $\begin{array}{l}\text { Maternal } \\
\text { age, years }\end{array}$ & Risk & $\begin{array}{l}\text { Rate } \\
\text { per } 1,000\end{array}$ & $\begin{array}{l}\text { Relative } \\
\text { risk }\end{array}$ \\
\hline 20 & $1 / 1,917$ & 0.52 & 1.00 \\
21 & $1 / 1,739$ & 0.58 & 1.10 \\
22 & $1 / 1,190$ & 0.84 & 1.61 \\
23 & $1 / 874$ & 1.14 & 2.19 \\
24 & $1 / 663$ & 1.51 & 2.89 \\
25 & $1 / 598$ & 1.67 & 3.20 \\
26 & $1 / 536$ & 1.86 & 3.57 \\
27 & $1 / 480$ & 2.08 & 3.99 \\
28 & $1 / 316$ & 3.16 & 6.06 \\
29 & $1 / 276$ & 3.62 & 6.93 \\
30 & $1 / 209$ & 4.78 & 9.16 \\
31 & $1 / 181$ & 5.52 & 10.57 \\
32 & $1 / 153$ & 6.54 & 12.51 \\
33 & $1 / 128$ & 7.81 & 14.95 \\
34 & $1 / 120$ & 8.33 & 15.95 \\
35 & $1 / 112$ & 8.93 & 17.09 \\
36 & $1 / 107$ & 9.34 & 17.89 \\
37 & $1 / 104$ & 9.62 & 18.40 \\
38 & $1 / 83$ & 12.50 & 23.06 \\
39 & $1 / 63$ & 15.87 & 30.38 \\
40 & $1 / 61$ & 16.39 & 31.38 \\
41 & $1 / 60$ & 16.66 & 31.90 \\
42 & $1 / 43$ & 23.26 & 44.51 \\
43 & $1 / 32$ & 31.25 & 59.81 \\
44 & $1 / 23$ & 43.50 & 83.22 \\
\hline & & & \\
\hline
\end{tabular}

$\chi^{2}$ for linear trend $=189.9 ; \mathrm{p}<0.001$.

$97.9 \%$, mosaic type $0.7 \%$ and translocation type $1.4 \%$ of the total trisomy 21 cases (table 2 ). Table 3 shows the incidence and sex ratio of the common trisomies. Tables 4 and 5 show the risk of trisomy 21 by maternal and

Profile of Chromosomal Abnormalities in the Al Jahra Region of Kuwait
Table 5. The risk of trisomy 21 by paternal age at delivery

\begin{tabular}{llll}
\hline $\begin{array}{l}\text { Paternal } \\
\text { age, years }\end{array}$ & Risk & $\begin{array}{l}\text { Rate } \\
\text { per } 1,000\end{array}$ & $\begin{array}{l}\text { Relative } \\
\text { risk }\end{array}$ \\
\hline 20 & $1 / 2,798$ & 0.36 & 1.00 \\
21 & $1 / 2,600$ & 0.38 & 1.08 \\
22 & $1 / 1,593$ & 0.63 & 1.76 \\
23 & $1 / 1,466$ & 0.68 & 1.91 \\
24 & $1 / 790$ & 1.27 & 3.54 \\
25 & $1 / 599$ & 1.67 & 4.67 \\
26 & $1 / 535$ & 1.87 & 5.23 \\
27 & $1 / 411$ & 2.43 & 6.81 \\
28 & $1 / 254$ & 3.93 & 11.02 \\
29 & $1 / 225$ & 4.44 & 12.44 \\
30 & $1 / 201$ & 4.98 & 13.92 \\
31 & $1 / 192$ & 5.21 & 14.57 \\
32 & $1 / 180$ & 5.56 & 15.54 \\
33 & $1 / 171$ & 5.85 & 16.36 \\
34 & $1 / 162$ & 6.17 & 17.27 \\
35 & $1 / 161$ & 6.21 & 17.27 \\
36 & $1 / 153$ & 6.54 & 18.29 \\
37 & $1 / 140$ & 7.14 & 19.99 \\
38 & $1 / 132$ & 7.58 & 21.20 \\
39 & $1 / 121$ & 8.26 & 23.12 \\
40 & $1 / 101$ & 9.90 & 27.70 \\
41 & $1 / 95$ & 10.52 & 29.45 \\
42 & $1 / 82$ & 12.20 & 34.12 \\
43 & $1 / 73$ & 13.70 & 38.33 \\
44 & $1 / 65$ & 15.38 & 43.05 \\
\hline & & & \\
$\chi^{2}$ for linear trend & $122.1 ; \mathrm{p}<0.001$ & \\
\hline & & & \\
\hline
\end{tabular}

paternal age at delivery. Both tables show the $\chi^{2}$ and the $\mathrm{p}$ value. It was found that there is an increase in trisomy 21 as either maternal or paternal age increases. Table 6 shows the adjusted odds ratio for the risk factors and their

Med Principles Pract 1999:8:167-172 
Table 6. Logistic regression analysis of 145 trisomy- 21 cases and 145 controls

\begin{tabular}{|c|c|c|c|}
\hline Variable & $\begin{array}{l}\text { Odds } \\
\text { ratio }\end{array}$ & $\begin{array}{l}95 \% \text { confidence } \\
\text { interval }\end{array}$ & $\mathrm{p}$ value \\
\hline Non-Bedouin & Ref. & - & - \\
\hline Bedouin & 1.819 & $1.052-3.145$ & 0.032 \\
\hline \multicolumn{4}{|l|}{ Maternal age } \\
\hline$\uparrow 20$ & Ref. & - & - \\
\hline $30-$ & 3.039 & $1.829-5.049$ & $<0.001$ \\
\hline $40+$ & 5.695 & $1.964-16.519$ & 0.001 \\
\hline \multicolumn{4}{|l|}{ Paternal age } \\
\hline$\uparrow 20-$ & Ref. & - & - \\
\hline $30-$ & 4.832 & $2.849-8.193$ & $<0.001$ \\
\hline $40+$ & 2.148 & $0.855-5.396$ & 0.104 \\
\hline
\end{tabular}

$95 \%$ confidence intervals after fixing the confounding effects. Bedouins are subjected to almost twofold risk of trisomy 21 as against the non-Bedouins (odds ratio $=1.819, \mathrm{p}=$ $0.032)$. As the maternal age increases (30-39 years) the risk of trisomy 21 is nearly tripled as compared to a lower age group (20-29 years). The maternal age group of $40+$ carries more than 5 times the risk for trisomy 21 in comparison to the age group of 20-29 years. On the other hand, paternal age showed a non-linear pattern. As the paternal age increases to the age group of 30-39 years, the risk increases 4 times in comparison to the age group of 20-29 years. In the paternal age of $40+$ years, the risk was twofold higher than that of the young paternal age group.

\section{Discussion}

Several previous reports and communications regarding chromosomal aberrations observed at the Kuwait Medical Genetics Centre have been published $[2-4,6,7,9-11]$. The overall incidence of numerical chromosomal abnormalities in the present study was 3.4/ 1,000 live births which is similar to the incidence reported in Evan's [12] study. At the same time the incidence of trisomy 21 was $2.9 / 1,000$ live births, which is close to the figure reported by Farag et al. [2] in the same region. Both figures are higher than the 1.1/ 1,000 live births previously reported from Kuwait [10], but similar to the incidence reported for Downs'syndrome among Negev Bedouins [13], and close to that reported in west Jerusalem [14]. The difference between the figures reported in the Al-Jahra region and that reported in other regions of Kuwait could be explained by the population pattern in this area ( $80 \%$ Bedouins) and the high rate of consanguineous marriage among those people. The average inbreeding coefficient $(\Sigma \mathrm{F})$ of babies with different autosomal trisomies was 0.044 , which is higher than that computed from other regions of Kuwait $(\Sigma \mathrm{F}=0.0219)$ [2-5]. In the present study, 2 cases of translocation type of trisomy 21 were reported with an incidence of $0.04 / 1,000$ live births which is close to the incidence reported by Wright et al. [15]. Hamerton [16] and Giraud and Mattei [17] reported double and triple the figure reported by us, respectively. The difference between the figures in the present study and those of the other studies could be explained by the possibility of missing some cases before the clinical and the cytogenetic assessments. In the present study, the sex ratio for trisomy 21 was M:F 2.1:1, which is similar to that reported by DeGrouchy and Turleau [1] and double that reported by Bernheim et al. [18] (M:F 1:1). The incidence of trisomy $18(0.3 /$ 1,000 live births) in our study is higher than the incidence $(0.1 / 1,000$ live births) reported by Sumnit [19] and Nelson et al. [20]. Even though our figure is lower than that reported earlier from the Al-Jahra Regional Hospital $(0.6 / 1,000$ live births) [2], it seems to be more realistic, as the earlier figure was calculated

\footnotetext{
$\overline{170} \quad \overline{\text { Med Principles Pract 1999;8:167-172 }}$
} 
for 1 year only. However, both figures confirmed trisomy 18 clustering in Kuwait. In the present study, trisomy 18 sex ratio showed preponderance to females $(1 \mathrm{M}: 3 \mathrm{~F})$, which is similar to the ratio reported by Schinzel [21]. The incidence of trisomy 13 was $0.1 / 1,000$ live births in our study and is similar to some of the earlier reports [22,23]. Trisomy 13 sex ratio also shows a female preponderance $(\mathrm{M}: \mathrm{F}$ 1:4), which is similar to the reports of Magenis et al. [23]. The present study includes a case of Turner's syndrome, with an incidence of 0.05 / 1,000 female live births. This incidence is considered low when compared to earlier reports that show double [24] and even 6 times [25] our figure. The difference between our figure and the other figures could be explained by the possibility of underestimation of the diagnosis of Turner's syndrome among newborns. Our study included 3 cases of cri-duchat with an incidence of $0.06 / 1,000$ live births, which is higher than the incidence reported by Niebuhr [26]. Other studies carried out in Kuwait reported a similar figure [3, 11]. Our computed figure is considered triple the Danish figure reported by Niebuhr [27]. Our study confirms the clustering of cri-duchat in Kuwait among Bedouins, which is so similar to the study by Farag et al. [3]. The other numerical and structural chromosomal abnormality cases are scarce and unreliable for statistical analysis. A question raised is, does the high consanguinity rate among Bedouins contribute to structural as well as numerical chromosomal abnormalities? We computed the risk of trisomy 21 among the liveborn babies included in our study in relation to the ethnicity, maternal and paternal age. Statistical analysis for the linear trend (chi-square) showed a significant increase in trisomy 21 as the maternal age increases $(\mathrm{p}=$ 0.001 ), which is highly significant while the paternal age effect was inconsistent. Hook [28] studied the maternal age effect on the incidence of trisomy 21 and reported an increased risk with the increase in maternal age above 35 years. At the same time he suggested that the increased risk at age $<15$ years may result from reporting errors and not from biological differences. The adjusted odds ratio for the risk factor confirmed the effect of ethnicity (Bedouins) as a risk factor for increasing trisomy $21(\mathrm{p}=0.032)$, which is a significant value. Advanced maternal age as a risk factor is also confirmed by the logistic regression ratio $(\mathrm{p}=0.001)$ which is highly significant. Little et al. [29] studied the effect of ethnicity and maternal age effects on the risk of chromosomal abnormality among the liveborn offspring. They reported an increase in the risk for trisomy-21 syndrome with advanced maternal age $>35$ years using the same statistical parameters [29]. On the other hand Yoon et al. [30] found that the association with meiosis 11 implies that there is at least one maternal age-related mechanism acting around the time of conception.

\section{Conclusion}

The present study confirmed the effect of ethnicity (Bedouins) and the advanced maternal and paternal age on the risk of having trisomy-21 babies. The paternal age had an inconsistent pattern. This study also confirmed the clustering of trisomy-18 and cridu-chat syndromes in Kuwait.

\section{Acknowledgement}

We would like to thank Dr. Mohamed Moussa, Department of Community Medicine and Behavioral Sciences, Faculty of Medicine, Kuwait University, for his faithful participation in the statistical reanalysis of the present work. 


\section{References}

1 De Grouchy J, Turleau C: Clinical Atlas of Human chromosomes. New York, Wiley \& Sons, 1985.

2 Farag TI, Al-Awadi SA, Al-Othman SA, Sundereshan TS, Krishna Murthy DS, Usha R, Mady SA, Uma R: Down syndrome and trisomy 18 in the Bedouins (letter). Am J Med Genet 1988;29:943-944.

3 Farag TI, Al-Awadi SA, Marafie MJ, Bastaki L, Murthy DS, Al-Othman SA, Mohamed FM, Reda AA, Abul Hasan SJ, Reda MA, et al: Clustering of cri-du-chat syndrome among the Bedouins. Am J Med Genet 1993;46:347-348

4 Farag TI, Krishna Murthy DS, AlAwady SA, Sundareshan TS, AlOthman SA, Mady SA, Reda MA: Robertsonian translocation of $\mathrm{t}, \operatorname{dic}(14 \mathrm{p} ; 22 \mathrm{p})$ with regular trisomy 21: A possible interchromosomal effect. Am J Med Genet 1987;30:189_ 192.

5 Al-Awadi SA, Teebi AS, Farag TI, Naguib KK, El-Khalifa MY, AlOthman SA, Sundareshan TS: A five year experience with autosomal abnormalities in Kuwait. J Kwt Med Assoc 1985;19:269-275.

6 Al-Awadi SA, Farag TI, Usha R, ElKhalifa MY, Sundareshan TS, AlOthman SA: Interstitial deletion of the long arm of chromosome one, del(1)(q32-q42). Am J Med Genet 1986;23:931-933.

7 Al-Awadi SA, Farag TI, Teebi AS, Naguib KK, Sundareshan TS, Krishna Murthy DS: Down syndrome in Kuwait. Am J Med Genet 1990(suppl 7):87-88.

8 Al-Awadi SA, Al-Othman SA, Mohammed FM, Abul Hassan SJ, Redha M, Farag TI, Naguib KK, Teebi AS, El-Khalifa MY, Marafie MJ, Bastaki L, Kahlan PS, Cuscheri A, Sundareshan TS, Krishna Murthy DS: Kuwait cytogenetics registry. 11 th Int Chromosome Conf, Edinburgh 1992, A2, p 71
9 Alfi OS, Chang R, Azen SP: Evidence for genetic control of nondisjunction in man. Am J Hum Genet 1980;32:477-483.

10 El-Alfi OS, Shaker YK, Shaath R, Abdel Salam T: Congenital malformations in Kuwait. J Kwt Med Assoc 1968;2:99-108.

11 Bastaki L: Major Congenital Malformations in Kuwait: A Clinicogenetic Study of 1062 among 81016 Consecutive Hospital Births; MSc diss Glasgow University, 1992.

12 Evans HJ: Chromosome anomalities among liverbirths. J Med Genet 1977;14:309-312.

13 Abeliovich D, Atia Y, Saro VD: Down's syndrome in Negev region. Am J Med Genet 1986;25:183.

14 Harlap S: Down's syndrome in west Jerusalem. Am J Epidemiol 1974; 97:225-232

15 Wright SW, Day RW, Muller H Weinhouse R: The frequency of trisomy and translocation in Down syndrome. J Pediatr 1967;70:420.

16 Hamerton JL: Robertsonian translocation in man: Evidence for prezygotic selection. Cytogenetics 1968; 7 266.

17 Giraud F, Mattei JF: Aspects epidemiologiques de la trisomie 21 . J Génét Hum 1975;23:1.

18 Bernheim A, Chastang CL, Heaulme M, De Grouchy JD: Excès de garçons dans la trisomie-21. Ann Génét 22:112.

19 Summit RL: Abnormalities of autosomes and their resultant syndromes. Pediatr Ann 1973;2:40.

20 Nelson J, Holm V, Haahr J: Prevalence of Edward's syndrome clustering and seasonal variation. Hum Genet 1975;26:113.

21 Schinzel A: A catalogue of Unbalanced Chromosome Aberrations in Man. Berlin, de Gruyter, 1984, pp 221-228.
22 Conen PE, Erkman B: Frequency and occurrence of chromosomal syndromes ID trisomy. Am J Hum Genet 1966;18:374-378.

23 Magenis RE, Hecht F, Milham S: Trisomy 13 (D1) syndrome: Studies on parental age, sex ratio and survival. J Pediatr 1968;73:222-228.

24 Hook EB, Cross PK, Regal RR: Frequency of $47,+21,47,+18$ and $47,+13$ at the upper most extremes of maternal ages: Results on 56,094 fetuses studied prenatally and comparisons with data on livebirths. Hum Genet 1984;68:211-220.

25 de la Chapelle A: Sex chromosome abnormalities; in Emry, Rimoin (eds): Principles and Practice of Medical Genetics, ed 2. Edinburgh, Churchill Livingstone, 1990.

26 Niebuhr E: Triploid in man: Cytogenetic and clinical aspects. $\mathrm{Hu}-$ mangenetik 1974;21:103-125.

27 Niebuhr E: The cri du chat syndrome: Epidemiology, cytogenetics and clinical features. Hum Genet 1978;44:227-275.

28 Hook EB: Maternal age, paternal age and human chromosome abnormality, nature, magnitude, etiology and mechanisms of effects. Basic Life Sci 1985;36:117-132.

29 Little BB, Ramin SM, Cambridge BS, Schneider NR, Cohen DS, Snell LM, Harrod MJ, Johnston WL: Risk of chromosomal abnormalities with emphasis on live-born offspring of young mothers. Am J Hum Genet 1995;57:1178-1185.

30 Yoon PW, Freeman SB, Sherman SL, Taft LF, Gu Y, Pettay D, Flanders WD, Khoury MJ, Hassold TJ: Advanced maternal age and risk of Down syndrome characterized by meiotic stage of chromosomal error: A population-based study. Am J Hum Genet 1996;58:628-633.
Al-Naggar/Mady/Tayel/Farag/ Al-Awadi/Al-Ghanim/Abulhasan/ Sabry/Bastaki 